\title{
PERAN APLIKASI WA SEBAGAI MEDIA PEMBELAJARAN DALAM MATA KULIAH METODOLOGI PENELITIAN
}

\author{
Abidah \\ STAIN Teungku Dirundeng, Meulaboh - Aceh \\ e-mail: abidah8383@gmail.com
}

\begin{abstract}
Social media is the most popular service at the moment. Its users can communicate with each other, interact, share network, and various other activities. Currently, one of the social media that can be used easily by students is WhatsApp (WA). More effort is needed to find creative ways to increase students' activity in learning. Looking the development of technology and the increasing number of users, the use of social media such as WA is very appropriate to be applied in the learning process. The use of WA in the learning process will give students the ability to get more information, more connected to lecturers, study group, and other education systems. It makes the learning process more interesting. This research was conducted to investigate the role of WA as a learning media in studying research methodology to increase student learning activities. The purposes of this research is to know to what extent WA instant messaging application can be used to improve learning activity in studying research methodology. The data was analysed using descriptive statistical method by using percentage. It was found that $94 \%$ of students improved their learning outcome in studying research methodology. The result of data analyzes showed a significant effect of the use of WA as a learning media in studying research methodology to increase student learning activities.
\end{abstract}

Keywords. learning, sosial media, WA, activity in learning.

\section{Abstrak}

Media sosial adalah layanan paling populer saat ini. Para penggunanya dapat berkomunikasi satu sama lain, berinteraksi, berbagi, jaringan, dan berbagai kegiatan lainnya. Saat ini, salah satu media sosial yang dapat digunakan dengan mudah oleh siswa adalah WA. Diperlukan lebih banyak upaya untuk menemukan cara-cara kreatif untuk meningkatkan aktivitas siswa dalam belajar. Penggunaan media sosial seperti WA sangat tepat untuk diterapkan dalam proses pembelajaran. Penggunaan WA dalam proses pembelajaran akan memberi siswa kemampuan untuk mendapatkan lebih banyak informasi, lebih terhubung dengan dosen, kelompok belajar, dan sistem pendidikan lainnya yang memiliki topik dan masalah yang sama. Hal ini membuat proses pembelajaran lebih menarik. Penelitian ini dilakukan untuk melihat peran aplikasi WA sebagai media dalam mempelajari metodologi penelitian untuk meningkatkan kegiatan belajar siswa. Tujuan dari penelitian ini adalah untuk mengetahui sejauh mana peran aplikasi pesan instan WA dapat digunakan untuk meningkatkan kegiatan pembelajaran dalam mempelajari metodologi penelitian. Data penelitian ini dianalisis dengan menggunakan metode statistik deskriptif dengan menggunakan persentase. Dari data didapat $94 \%$ mahasiswa setuju untuk menggunakan WA dalam belajar mata kuliah metodologi penelitian. Hasil data yang ditampilkan terbukti bahwa peran aplikasi WA memiliki efek 
signifikan sebagai media untuk mempelajari metodologi penelitian sehingga meningkatkan kegiatan belajar siswa.

Kata kunci. belajar, media sosial, WhatsApp, aktivitas dalam belajar.

\section{PENDAHULUAN}

Teknologi saat ini semakin banyak digunakan baik di dalam maupun di luar kelas. Jadi sangat penting untuk menerima teknologi baru dan menerapkan manfaatnya dalam sistem pendidikan. Dalam prakteknya, lembaga pendidikan masih mengandalkan sistem manajemen pembelajaran tradisional yang tidak sepenuhnya memanfaatkan potensi media sosial untuk memungkinkan partisipasi dalam jaringan pembelajaran global, kolaborasi dan jejaring sosial. Sementara itu, teknologi partisipasi Web 2.0 telah menjadi bagian penting dari kehidupan sehari-hari mahasiswa, bahkan sangat sedikit pelajar yang memberikan perhatian penuh terhadap teknologi ini untuk mendukung proses belajar mereka. ${ }^{1}$

Pelajar dan pengajar saat ini hidup di dunia Facebook, Twitter, Wikipedia, YouTube dan WA. Banyak aplikasi jejaring sosial dan media sosial lainnya yang merupakan bagian dari apa yang disebut Web Sosial. Hal ini ditandai dengan gagasan interaksi sosial, berbagi konten, dan kecerdasan kolektif. Selain itu, siswa saat ini telah menghabiskan sebagian besar waktu mereka di komputer, bermain game, pemutar musik digital, kamera video, ponsel, serta Web itu sendiri. Karena terbiasa dengan keterlibatan yang terus-menerus dan melakukan banyak tugas dalam kegiatan sehari-hari mereka, siswa memerlukan tingkat sosial dan keaktifan belajar

1 Li N, dkk, "Using Social Media for Collaborative Learning in Higher Education: A Case Study Using Social Media for Collaborative Learning in Higher Education," ACHI (2012), h. 285-290.

88 | BIDAYAH: Volume 11, No. 1, Juni 2020 yang tinggi dalam pembelajaran. Sedangkan pendekatan pengajaran tradisional fokus pada konten pasif, oleh sebab itu, tidak lagi berlaku dan harus diganti, atau setidaknya dilengkapi, dengan proses pembelajaran yang sangat interaktif. $^{2}$

Teori connectivism mengakui bahwa sifat digital dan jaringan dari kehidupan kita sehari-hari membutuhkan pembelajaran yang terjadi melalui interaksi dengan berbagai sumber pengetahuan dan partisipasi dalam komunitas yang memiliki kepentingan bersama, jejaring sosial, dan tugas kelompok. ${ }^{3}$ Teori pembelajaran ini juga menekankan peran penting yang dimainkan teknologi dalam proses pembelajaran dan hubungan individu dengan teknologi serta sesama individu lain dengan menggunakan teknologi. Selain itu, penggunaan media sosial seperti WA dalam pendidikan memberikan siswa/mahasiswa kemampuan untuk mendapatkan informasi yang lebih bermanfaat, saling terhubung dengan kelompok belajar dan sistem pendidikan lainnya yang membuat proses pembelajaran lebih menarik nyaman. ${ }^{4}$

Selain itu, aplikasi WA memiliki

2 Raymond Chiong, dkk, "Social Networking , Teaching, and Learning, Interdiscip.," J. Information, Knowledge, Manag., vol. 7, (2012), h. 39-43.

3 George Siemens, "Connectivism: Learning Theory For The Digital Age," Int. J. Instruc-tional Technol. Distance Learn, (2005), h.2-3.

4 LCIBS, "The Role of Social Media in Education," London College Of International Business Studie, (https://www.lcibs.co.uk/the-role-of-socialmedia-in-education, 2019), h. 3. 
banyak fitur obrolan, salah satunya adalah obrolan grup atau group chat. Fitur tersebut memungkinkan banyak pengguna WA mengobrol dalam sebuah ruang obrolan yang biasa disebut sebagai grup, dengan jumlah maksimal anggota sebanyak 250 pengguna. Obrolan grup dalam layanan WA dapat dibuat tanpa syarat, dan pembuat grup dapat menambahkan anggota hingga mencapai batas maksimal. ${ }^{5}$

Bertolak dari fakta-fakta tersebut, lewat penelitian ini penulis berupaya memanfaatkan fasilitas yang disediakan layanan pesan instan WA untuk digunakan sebagai salah satu sumber belajar mandiri pada mata kuliah metodologi penelitian untuk meningkatkan keaktifan belajar mahasiswa. Dosen dapat menyampaikan materi-materi yang telah teringkas dalam bentuk slide menggunakan fitur pengiriman lampiran pada obrolan. Aplikasi WA sendiri dipilih dengan pertimbangan bahwa layanan ini memiliki paling banyak pengguna dibandingkan dengan layanan lain yang sejenis. Hasil survei peneliti juga menunjukkan bahwa WA merupakan aplikasi yang banyak digunakan oleh mahasiswa. Penggunaan layanan pesan instan WA sebagai media pembelajaran diharapkan dapat membantu peserta didik mendapatkan sumber belajar tambahan untuk mata kuliah metodologi penelitian

5 Singgih Hutomo Aji, "Pengembangan Aplikasi Layanan Pesan Instan WA Sebagai Sumber Belajar Mandiri Untuk Meningkatkan Motivasi Dan Hasil Belajar Fisika Materi Pokok Efek Rumah Kaca Peserta Didik Kelas XI SMA N 1 Purwokerto," Program Studi Pendidikaan Fisika Fakultas Matematika Dan Ilmu Pengetahuan Alam Universitas Negeri Yogyakarta, (2018), h.7. dan dapat merubah anggapan tentang metodologi penelitian yang dianggap kurang menarik menjadi lebih menarik, sehingga dapat meningkatkan keaktifan mahasiswa dalam belajar sehingga dapat meningkatkan hasil belajar mereka.

Perkembangan zaman telah mempengaruhi berbagai sendi kehidupan. Pengaruh perubahan zaman tersebut juga tidak dapat dihindari pada perkuliahan metodologi penelitian terutama bagi mahasiswa tingkat akhir yang sedang menyusun skripsi. Penggunaan media sosial yang sesuai harus dapat dimanfaatkan dengan optimal. Selain itu, komunikasi dan interaksi dalam media sosial juga harus diperhatikan. Karena terkadang media sosial selain memberikan manfaat juga tidak jarang menimbulkan dampak negatif bagi pengguna yang kurang bijaksana. Sebagai pendidik masa depan, sudah sepatutnya seorang pendidik mampu memanfaatkan segala yang tersedia dan berusaha mengubah potensi negatif menjadi bermanfaat. Potensi inilah yang dapat ditemukan dalam media sosial yang sudah menjamur bahkan mempengaruhi pola pikir masyarakat. Salah satu contoh media sosial yang sudah cukup menjamur bahkan hampir semua masyarakat telah menggunakannya adalah aplikasi WA. Aplikasi yang jumlah penggunaannya sudah bertambah banyak dari segala tingkat sosial. ${ }^{6}$

Pengguna WA sudah menjamur dengan menduduki peringkat teratas. Bertambahnya jumlah pengguna ini tidak lepas dari mudahnya

6 Agus Suyudi dan Khusaini Khusaini, "Optimalisasi Penggunaan WA dalam Perkuliahan Penilaian Pendidikan Fisika," JRKPF UAD, 4. (1), (https://www.researchgate.net/publication/320221403, 2017), h. 1-2. 
mengunduh aplikasi dari Google Store maupun semakin banyaknya pengguna smartphone terutama yang berjenis android. Manusia semakin mudah berinteraksi untuk mengirimkan pesan, berdiskusi, hingga membentuk grup tertentu untuk tujuan tertentu. Hal ini juga tidak lepas dari kecilnya usaha komersialisasi dari WA yang meniadakan iklan pada aplikasinya. Semakin bertambahnya pengguna inilah yang mendorong Facebook mengakuisisi perusahaan tersebut pada tahun $2014 .^{7}$

Pentingnya pemanfaatan WA dalam perkuliahan inilah yang mendorong perlunya penelitian dalam penggaplikasian sosial media terutama WA untuk meningkatkan keprofesionaln pendidik masa depan. Penelitian ini berusaha memberikan gambaran awal pengaplikasian WA dalam perkuliahan metodologi penelitian. Tulisan ini akan memberikan gambaran pentingnya interaksi dan peningkatan kualitas komunikasi dosen - mahasiswa dalam kegiatan perkuliahan. Gambaran ini yang selanjutnya menjadi pemicu bagi meningkatnya profesionalitas pendidik masa depan dalam melayani dan mendorong mahasiswa untuk belajar lebih aktif.

\section{LANDASAN TEORI}

\section{Media pembelajaran}

Proses belajar tidak sekedar menghafal konsep atau fakta belaka, tetapi lebih merupakan kegiatan internalisasi antar konsep guna menghasilkan pemahaman utuh. Menurut Ah-

"Akuisisi Facebook Terhadap WA Rampung," http://m. tempo.co/read/news/2014/10/07/090612453/akuisisi facebook-terhadap-WA-rampung, 2014, hal. 1. madi dan Amri belajar lebih bermakna jika individu mengalami langsung apa yang dipelajari dengan cara mengaktifkan secara maksimal potensi inderawi mereka daripada hanya mendengarkan. Selain itu, salah satu faktor yang ada di luar diri peserta didik adalah tersedianya media pembelajaran, yang memberikan kemudahan bagi peserta didik untuk mempelajari materi pembelajaran sehingga menghasilkan belajar yang lebih berkembang lagi. ${ }^{8}$

Penggunaan media pembelajaran pada tahap pembelajaran akan sangat membantu keefektifan proses pembelajaran dan penyampaian pesan serta isi pelajaran pada saat itu. Sadiman berpendapat bahwa media adalah segala sesuatu yang dapat digunakan untuk menyalurkan pesan dari pengirim ke penerima sehingga dapat merangsang pikiran, perasaan, perhatian dan minat siswa sedemikian rupa sehingga proses belajar terjadi. ${ }^{9}$ Media berperan sebagai jalan atau perantara antara yang menyampaikan yaitu guru dengan yang menerima yaitu peserta didik sebagai suatu kesatuan yang tak terpisahkan dalam prosesnya. Di samping itu Sudjana dan Rivai menyatakan bahwa kedudukan media pengajaran adalah sebagai alat bantu mengajar. Media pembelajaran dapat mempertinggi intensitas proses belajar peserta didik dalam pembelajaran yang diharapkan dapat mempertinggi hasil belajar yang dicapai peserta didik. ${ }^{10}$ Oleh

8Ahmadi dan Amri Sofyan, PAIKEM GEMBROT ( Pengembangan Pembelajaran Aktif, Inovatif, Kreatif, Efektif, Menyenangkan, Gembira dan Berbobot, (Jakarta : PT Prestasi Pustakaraya, 2011).

9 Arif S Sadiman, dkk, Media

Pendidikan: Pengertian, Pengembangan, dan Pemanfaatannya, (Jakarta: Rajawali Pers. 2010), h.7. 10 Nana Sudjana dan Ahmad Rivai, Media Pengajaran, (Bandung: Sinar Baru Algensindo, 2013), h. 1-2. 
karena itu dalam proses belajar mengajar peran media belajar sangat penting untuk diperhatikan. Dengan menggunakan media yang baik maka perhatian peserta didik dalam memperhatikan pelajaran akan lebih terfokus.

Selain media belajar dalam proses belajar mengajar keaktifan siswa juga sangat besar peranannya terhadap hasil belajar. Penggunaan media yang tepat dalam pembelajaran memperlancar penyampaian informasi kepada peserta didik sehingga dapat berfungsi untuk meningkatkan keaktifan peserta didik dalam mengikuti proses pembelajaran. Hadirnya media pembelajaran pada saat proses belajar mengajar dapat menimbulkan keaktifan peserta didik untuk mau lebih lanjut mengetahui atau mempelajari materi yang diberikan. Terutama pada materi yang dianggap lebih banyak terdapat teori dan hafalan-hafalan didalamnya. ${ }^{11}$ Seperti halnya mata kuliah metodologi penelitian. Untuk mata kuliah metodologi penelitian, jika dosen hanya menggunakan metode ceramah saja, tanpa menggunakan alat bantu media pembelajaran, maka peserta didik akan merasa bosan dan tidak memiliki motivasi lebih besar lagi untuk mau belajar atau mendengarkan materi yang diberikan oleh guru atau dosen.

Penggunaan media tidak dilihat atau dinilai dari segi kecanggihan medianya, tetapi yang paling penting adalah fungsinya dalam membantu mempertinggi proses pembelajaran.

11 Singgih Hutomo Aji "Pengembangan Aplikasi Layanan Pesan Instan WA Sebagai Sumber Belajar Mandiri Untuk Meningkatkan Motivasi Dan Hasil Belajar Fisika Materi Pokok Efek Rumah Kaca Peserta Didik Kelas XI SMA N 1 Purwokerto," Program Studi Pendidikaan Fisika Fakultas Matematika Dan Ilmu Pengetahuan Alam Universitas Negeri Yogyakarta, 2018), h.16.
Oleh karena itu dalam memilih media, seorang guru harus memperhatikan dan mempertimbangkan media mana yang dianggap tepat untuk menunjang pencapaian tujuan pembelajaran. Seperti yang dikatakan Suprihatiningrum, dalam dunia pendidikan dan pembelajaran, media diartikan sebagai alat dan bahan yang membawa informasi atau bahan pelajaran yang bertujuan mempermudah mencapai tujuan pembelajaran. Dalam proses pembelajaran, hadirnya media sangat diperlukan. Hal ini dikarenakan belajar tidak selamanya hanya bersentuhan dengan halhal yang kongkrit, baik dalam konsep maupun faktanya. Bahkan dalam realitasnya belajar seringkali bersentuhan dengan hal-hal yang bersifat kompleks, maya dan berada dibalik realitas. Karena itu media memiliki andil untuk menjelaskan hal-hal yang abstrak dan menunjukkan hal-hal yang tersembunyi. ${ }^{12}$

\section{Aplikasi WA Sebagai Media Pembelaja- ran}

Dalam pembelajaran dibutuhkan pemanfaatan alat bantu atau media untuk menyampaikan materi pembelajaran agar mudah diterima oleh peserta didik. Media pembelajaran merupakan salah satu alat dalam membantu mempermudah proses penyampaian informasi. Media pembelajaran yang digunakan saat ini tidak terbatas pada penggunaan papan tulis, alat praktikum dan buku-buku pelajaran, tetapi telah berkembang menggunakan sarana yang lebih canggih seiring majunya teknologi. Bentuk-bentuk media yang sebelumnya identik dengan dimensi fisik yang besar kini semakin

12 Jamil Suprihatiningrum,. Strategi Pembelajaran Teori dan Aplikasi, (Yogyakarta: ARRuzz Media, 2013), h. 319. 
berkembang menjadi bentuk digital yang lebih kompak, ringkas, dan portabel. Salah satu potensi dari teknologi yang dapat dimanfaatkan sebagai media pembelajaran adalah pemanfaatan ponsel pintar (smartphone) dan internet. Kombinasi dari teknologi tersebut menciptakan layanan pesan instan (instant messaging) pada ponsel, salah satu layanan pesan instan tersebut adalah WA. Aplikasi layanan WA adalah aplikasi pesan ponsel alternatif yang menggunakan sambungan data internet atau WiFi tanpa diperlukan tambahan biaya selain biaya sambungan data internet dan merupakan layanan pesan instan yang paling banyak digunakan di Indonesia. WA memiliki berbagai fitur-fitur terkait obrolan, salah satunya adalah obrolan grup atau group chat. Fitur tersebut memungkinkan beberapa pengguna WA untuk melakukan obrolan dalam satu ruang obrolan sehingga ketika salah satu anggota dalam grup mengirimkan pesan atau media ke dalam grup, seluruh anggota dapat menerima dan membaca secara bersamaan. Fitur inilah yang dapat dimanfaatkan sebagai media sumber belajar mandiri peserta didik. ${ }^{13}$

Dalam mengajar mata kuliah metodologi penelitian, dosen dapat memberikan materimateri yang telah teringkas kepada mahasiswa melalui layanan WA. Media ini juga bersifat portabel, kompak, dan praktis untuk digunakan dimanapun karena berbentuk digital. Bentuk digital yang hanya memerlukan ruang pada piranti penyimpanan digital yang relatif kecil

13 Singgih Hutomo Aji, "Pengembangan Aplikasi Layanan Pesan Instan WA Sebagai Sumber Belajar Mandiri Untuk Meningkatkan Motivasi Dan Hasil Belajar Fisika Materi Pokok Efek Rumah Kaca Peserta Didik Kelas XI SMA N 1 Purwokerto," Program Studi Pendidikaan Fisika Fakultas Matematika Dan Ilmu Pengetahuan Alam Universitas Negeri Yogyakarta, (2018), h.45 - 46.

92 | BIDAYAH: Volume 11, No. 1, Juni 2020 menjadikan media sangat mudah untuk dikelola. Implementasi layanan WA sebagai sumber belajar mandiri dapat membantu peserta didik dalam memahami materi yang akan dipelajari di kelas. Materi berbentuk digital yang ringkas serta penggunaan yang praktis pada ponsel dengan layanan WA dapat membangkitkan motivasi peserta didik dalam belajar sehingga dapat meningkatkan pencapaian hasil belajar. Penyusunan materi kedalam bagian yang lebih kecil dilakukan sebagai upaya meningkatkan percaya diri peserta didik serta mempermudah dalam pemahaman karena materi tidak diberikan dalam jumlah banyak secara langsung.

Penelitian oleh Baskoro Hadi tentang pemanfaatan aplikasi WA pada pembelajaran berbasis blended learning di SMKN 1 Sragen menyatakan bahwa memanfaatkan ponsel pintar dengan aplikasi WA dapat menjadi pendukung keberhasilan proses belajar mengajar. ${ }^{14}$ Selain itu, penelitian yang dilakukan oleh Khusaini, Agus Suyudi, Winarto dan Sugiyanto dengan judul optimalisasi penggunaan WA dalam perkuliahan penilaian pendidikan fisika menunjukkan adanya pengaruh positif dari penggunaan WA bagi keaktifan mahasiswa dalam berdiskusi baik dalam perkuliahan tatap muka maupun dalam jaringan (daring). Kedekatan serta diskusi antar mahasiswa dan dosen-mahasiswa dapat terjadi dengan baik serta meningkatkan motivasi belajar mahasiswa. ${ }^{15}$

Selain itu, penelitian oleh Ahmad Taufiq

14 Baskoro Hadi, "Pemanfaatan Aplikasi WA Pada Pembelajaran Berbasis Blended Learning di SMKN 1 Sragen," https://jurnal.fkip.uns.ac.id/index.php/ teknodika/article/view/8276, (2015), h.1.

15 Agus Suyudi dan Khusaini Khusaini, "Optimalisasi Penggunaan WA dalam Perkuliahan Penilaian Pendidikan Fisika," JRKPF UAD, 4. (1), (https://www.researchgate.net/publication/320221403, 2017), h. 4. 
dengan judul efektifitas pembelajaran Bahasa Arab melalui media sosial WA di program BISA (belajar Islam dan Bahasa Arab). Penelitian deskriptif kualitatif ini menunjukkan dari 20 peserta Program BISA angkatan 11 dan 12 yang dijadikan responden, $95 \%$ mengatakan efektif yaitu sebanyak 19 orang dan semua merasa senang dalam mempelajari bahasa arab melalui media sosial WA. ${ }^{16}$

Selain itu juga, hasil penelitian oleh Arini Izzati Khairina dengan judul pengembangan media sosial WA sebagai media pembelajaran Bahasa Arab di SMP IT Masjid Syuhada Yogyakarta menunjukkan produk media pembelajaran Bahasa Arab berbasis media sosial WA berupa media visual dengan kelayakan pengembangan media masuk ke dalam kriteria sangat layak digunakan sebagai penunjang pembelajaran bahasa Arab kelas VIII di SMP IT Syuhada Yogyakarta. ${ }^{17}$ Penelitian oleh Singgih Hutomo Aji dengan judul pengembangan aplikasi layanan pesan instan WA sebagai sumber belajar mandiri untuk meningkatkan motivasi dan hasil belajar fisika materi pokok efek rumah kaca peserta didik kelas XI SMAN 1 Purwokerto menyatakan bahwa media sumber belajar mandiri berbasis aplikasi layanan pesan instan WA yang dikembangkan dinyatakan layak dengan penilaian validator pada seluruh aspek masuk dalam kategori sangat baik dan media sumber belajar mandiri berbasis aplikasi layanan pesan instan

16 Ahmad Taufiq Ma'mun, "Efektifitas Pembelajaran Bahasa Arab Melalui Media Sosial WA di Program BISA (Belajar Islam dan Bahasa Arab)," Fakultas Tarbiyah dan Keguruan, UIN Sunan Kalijaga Yogyakarta, (2015), h. 8.

17 Arini Izzati Khairina, "Pengembangan Media Sosial WA Sebagai Media Pembelajaran Bahasa Arab di SMP IT Masjid Syuhada Yogyakarta," Program Studi Pendidikan Islam, UIN Sunan Kalijaga, Yogyakarta, (2016), h.8.
WA dapat digunakan untuk meningkatkan motivasi dan hasil belajar peserta didik. ${ }^{18}$

\section{Keaktifan Belajar Dalam Perkuliahan}

Keaktifan belajar dalam perkuliahan sangat diperlukan, karena dengan keaktifan ini parapelajarakan dapat meningkatkan potensinya terhadap materi kuliah. Menurut kamus besar bahasa Indonesia aktif berarti giat (bekerja atau berusaha), sedangkan keaktifan diartikan sebagai hal atau keadaan dimana mahasiswa dapat aktif. Dengan demikian keaktifan didapat dari dalam proses pembelajaran. Apabila mahasiswa aktif maka mahasiswa dapat mengembangkan sendiri potensi yang ada pada diri mereka. Hal tersebut dapat dilakukan dengan belajar mandiri seperti mempelajari bahan belajar melalui WA, oleh sebab itu perlu diciptakan pembelajaran aktif untuk mendukung potensi mahasiswa. Pembelajaran aktif (active learning) dimaksudkan untuk mengoptimalkan penggunaan semua potensi yang dimiliki oleh peserta didik, sehingga semua peserta didik

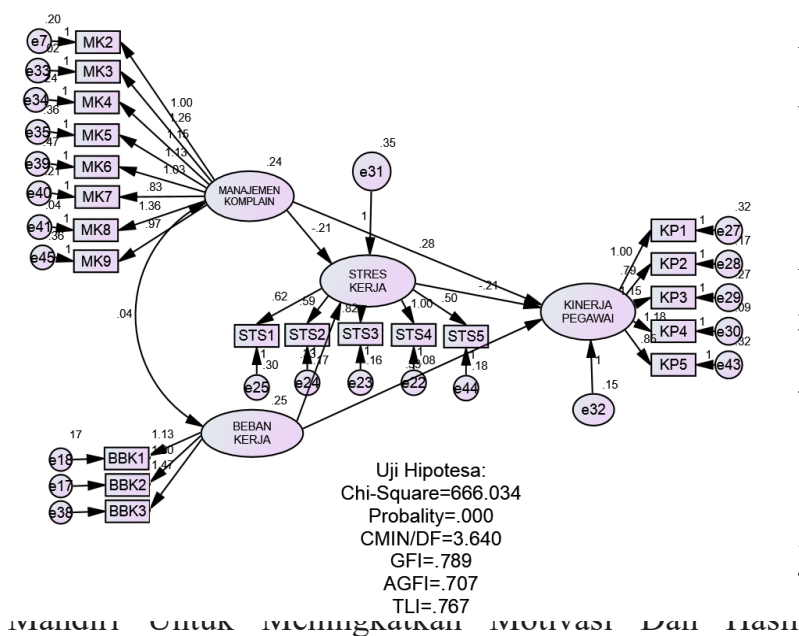

Belajar Fisika Materi Pokok Efek Rumah Kaca Peserta Didik Kelas XI SMA N 1 Purwokerto," Program Studi Pendidikaan Fisika Fakultas Matematika Dan Ilmu Pengetahuan Alam Universitas Negeri Yogyakarta, (2018), h. 2.

19 Eveline Siregar, dkk, Teori Belajar dan Pembelajaran, (Bogor: Ghalia Indonesia, 2010), h.106. 
Sedangkan menurut Ulil keaktifan belajar adalah kegiatan atau kesibukan peserta didik dalam kegiatan belajar mengajar di sekolah maupun di luar sekolah yang menunjang keberhasilan peserta didik. Jadi keaktifan belajar adalah upaya peserta didik dalam mengembangkan potensi diri melalui kegiatan belajar untuk mencapai tujuan belajar. ${ }^{20}$ Menurut Usman, cara yang dapat digunakan pendidik untuk memperbaiki keterlibatan peserta didik antara lain dengan meningkatkan persepsi peserta didik secara aktif dalam kegiatan belajar mengajar sehingga mendapatkan respon yang aktif dari peserta didik, melakukan masa transisi antara kegiatan dalam mengajar dengan cepat dan luwes, memberikan materi ajar yang jelas dan tepat sesuai dengan tujuan mengajar yang akan dicapai,mengusahakan agar pengajaran dapat lebih memacu minat peserta didik. Jadi, keaktifan belajar melalui pesan WA salah satu cara yang dapat meningkatkan kemampuan peserta didik secara mandiri dan aktif dalam proses pembelajaran. ${ }^{21}$

Selain itu, keaktifan peserta didik dalam proses pembelajaran dapat meransang dan mengembangkan bakat yang dimilikinya. Hal ini untuk melatih peserta didik agar dapat berpikir kritis dan dapat memecahkan berbagai permasalahan dalam kehidupan sehari -hari. Di samping itu, pendidik juga dapat merencanakan sistem pembelajaran secara sistematis, sehingga

20 Ulil Alpiyah, "Keaktifan Belajar Siswa Disekolah Ditinjau Dari Metode Pembelajaran Guru Dan Kelengkapan Fasilitas Sekolah Pada Mata Pelajaran Ekonomi Siswa Kelas VII MTS Yasi Kronggen Tahun Pelajaran 2012/2013," FKIP Universitas Muhammadiyah Surakarta, (2013), h. 12.

21 Moh. Uzer Usman, Menjadi Guru Profesional, (Bandung: PT Remaja Rosdakarya, 2002), h. 26.

94 | BIDAYAH: Volume 11, No. 1, Juni 2020 merangsang keaktifan peserta didik dalam proses pembelajaran. Gagne dan Briggs dalam Martinis mengatakan bahwa faktor- faktor yang dapat menumbuhkan timbulnya keaktifan peserta didik dalam proses pembelajaran, yaitu: 1) memberikan dorongan atau menarik perhatian peserta didik, sehingga mereka dapat berperan aktif dalam kegiatan pembelajaran, 2) menjelaskan tujuan instruksional (kemampuan dasar kepada peserta didik), 3) mengingatkan kompetensi belajar kepada peserta didik, 4) memberikan stimulus (masalah, topik, dan konsep yang akan dipelajari), 5) memberi petunjuk kepada peserta didik cara mempelajarinya, 6) memunculkan aktivitas, partisipasi peserta didik dalam kegiatan pembelajaran, 7) memberi umpan balik (feed back), 8) melakukan tagihan - tagihan kepada peserta didik berupa tes, sehingga kemampuan mereka selalu terpantau dan terukur, dan 9) menyimpulkan setiap materi yang disampaikan di akhir pembelajaran. ${ }^{22}$

Menurut Dimyati \& Mudjiono indikator keaktifan mencakup antaranya: 1) peserta didik mau mencatat atau sekedar mendengarkan penjelasan guru, 2) peserta didik memperhatikan hal-hal yang dijelaskan oleh guru tentang materi pelajaran, 3) peserta didik mencatat tugas yang diberikan dan mengerjakan tugas rumah, 4) peserta didik mau berdiskusi dalam kelompok untuk memecahkan masalah yang berkaitan dengan pelajaran, 5) peserta didik mampu melibatkan diri dalam proses tanya jawab dalam kelas, 6) peserta didik mau terlibat dalam menyimpulkan pembelajaran bersama guru dan

22 Martinis Yamin, Kiat Membelajarkan Siswa, (Jakarta: Gaung Persada Pres, 2007), h. 84. 
teman-teman lainnya. ${ }^{23}$

Sudjana berpendapat bahwa keaktifan peserta didik dalam mengikuti proses belajar mengajar dapat dilihat dari beberapa hal yaitu: 1) ketika kegiatan belajar mengajar berlangsung peserta didik turut serta melaksanakan tugas belajarnya, 2) peserta didik mau terlibat dalam pemecahan masalah dalam kegiatan pembelajaran, 3) peserta didik mau bertanya kepada teman atau kepada guru apabila tidak memahami, menemui kesulitan, 4) peserta didik mau berusaha mencari informasi yang diperlukan untuk pemecahan persoalan yang sedang dihadapinya, 5) peserta didik melakukan diskusi kelompok sesuai dengan petunjuk guru, 6) peserta didik mampu menilai kemampuan dirinya dan hasil -hasil yang diperolehnya, 7) peserta didik berlatih memecahkan soal atau masalah, 8) peserta didik memiliki kesempatan menggunakan atau menerapkan apa yang telah diperolehnya dalam menyelesaikan tugas atau persoalan yang dihadapinya. ${ }^{24}$

\section{METODOLOGI PENELITIAN}

Penelitian ini menggunakan observasi

23 Dimyati dan Mudjiono, Belajar dan Pembelajaran, (Jakarta: PT Rineke Cipta, 2006), h.45.

24 Nana Sudjana, Penilaian Hasil Proses Belajar Mengajar, (Bandung: PT. Remaja Rosdakarya, 2006), h. 61. dilakukan selama proses perkuliahan berlangsung selama satu semester berjalan.

\begin{tabular}{|c|l|c|c|}
\hline No & \multicolumn{1}{|c|}{ Pernyataan } & Ya & Tidak \\
\hline 1 & $\begin{array}{l}\text { Karena dengan aplikasi WA membantu kami apabila ingin } \\
\text { berdiskusi dengan bapak/ ibu dosen. Karena terkadang } \\
\text { untuk tatap muka langsung sulit untuk dilakukan. }\end{array}$ & & \\
\hline 2 & Membantu sekali & & \\
\hline
\end{tabular}

Peran Aplikasi Wa Sebagai Media Pembelajaran ..., | 95

dan angket dalam usaha mengumpulkan data. Observasi dan angket yang digunakan pada pengumpulan data ini menggunakan pendekatan kuantitatif sehingga bersifat terbuka dan memberikan kesempatan bagi responden untuk mengungkapkan pengalaman mereka selama mengikuti perkuliahan mata kuliah metodologi penelitian dengan menggunakan WA sebagai sarana komunikasi, diskusi, dan bertukar pikiran. Tiga puluh lima orang responden terlibat dalam kegiatan penelitian ini. Semua responden merupakan mahasiswa prodi HPI dan HES jurusan Syari'ah STAIN Teungku Dirundeng Meulaboh yang mengambil mata kuliah metodologi penelitian semester ganjil tahun akademik 2019/2020. Mahasiswa diberikan kesempatan untuk merespon dengan menggunakan mengisi angket tersebut. Mahasiswa memerlukan waktu sekitar 10 menit untuk mengisi angket tersebut dan tidak ada batasan waktu atau tempat untuk mengisi angket tersebut. Kegiatan observasi juga merupakan salah satu metode pengumpulan data yang digunakan. Peneliti melakukan pengamatan terhadap kegiatan perkuliahan di kelas. Observasi menggunakan model terbuka sebagai catatan lapangan untuk merekam semua fenomena yang dianggap menarik oleh pengamat selama kegiatan perkuliahan. Hasil pengamatan ini nanti akan dijadikan sebagai bahan pengayaan hasil penelitian yang telah diperoleh dari angket. Kegiatan observasi ini 


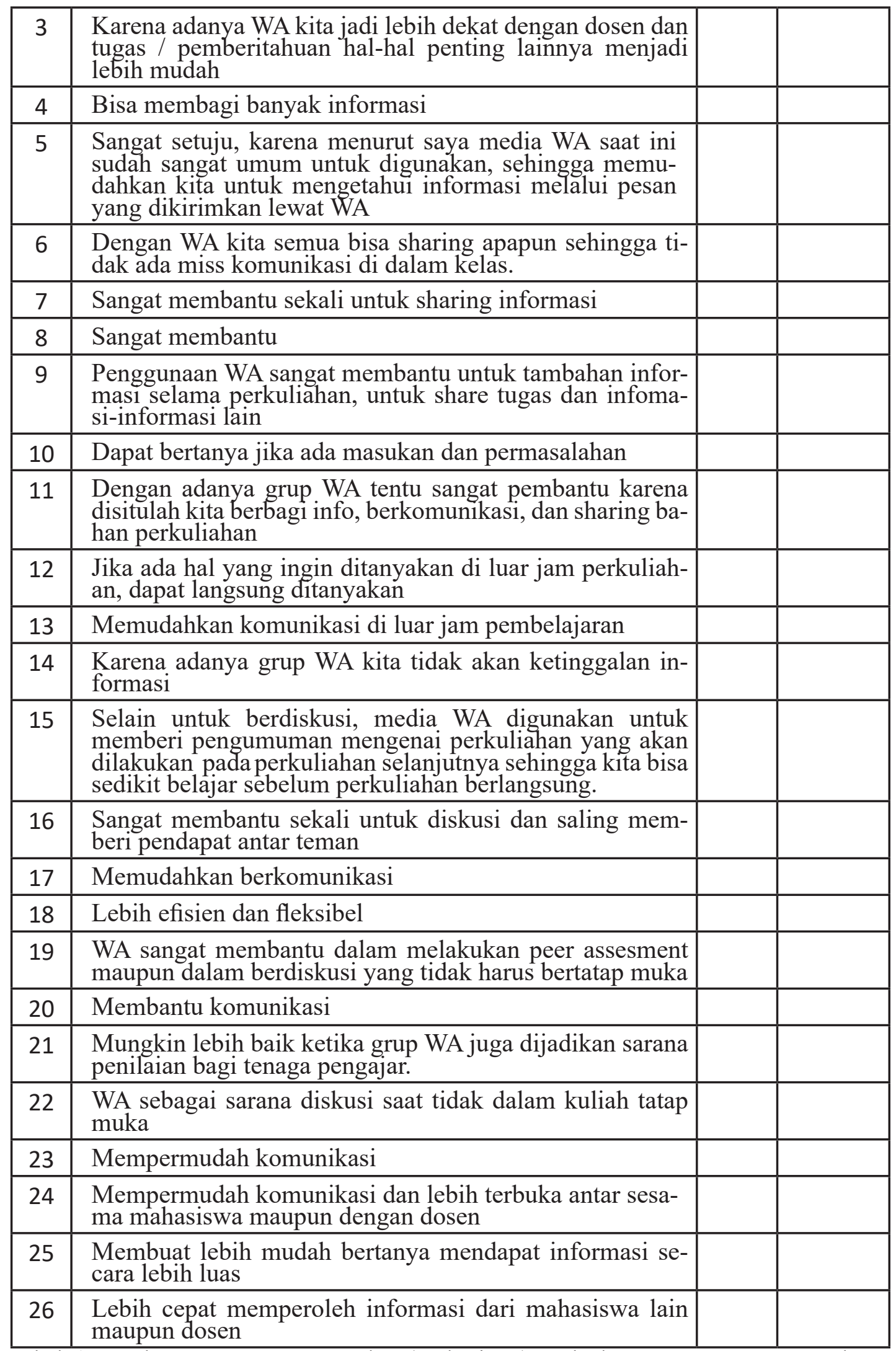

Tabel 1; Angket Komentar Responden (Mahasiswa) Terhadap Penggunaan WA Dalam Kegiatan Perkuliahan 


\section{HASIL DAN PEMBAHASAN}

Penelitian ini menunjukkan hasil yang menarik. Responden yang telah memberikan respon di angket, memberikan balikan yang positif terhadap penerapan kegiatan perkuliahan dengan menggunakan sarana WA. Hasil yang ditemukan menunjukkan $94.17 \%$ mahasiswa terbantu dengan penggunaan WA sebagai sarana komunikasi dalam kegiatan pembelajaran (Tabel 2). Hasil penelitian ini sejalan dengan hasil penelitian oleh Arini Izzati Khairina dengan judul pengembangan media sosial WA sebagai media pembelajaran Bahasa Arab di SMP IT Masjid Syuhada Yogyakarta yang menunjukkan produk media pembelajaran bahasa Arab berbasis media sosial WA berupa media visual dengan kelayakan pengembangan media masuk ke dalam kriteria sangat layak digunakan sebagai penunjang pembelajaran bahasa Arab kelas VIII di SMP IT Syuhada Yogyakarta. Hasil penelitian yang sama juga dikemukakan oleh Singgih Hutomo Aji yang menyatakan bahwa media sumber belajar mandiri berbasis aplikasi layanan pesan instan WA yang dikembangkan dinyatakan layak dengan penilaian validator pada seluruh aspek masuk dalam kategori sangat baik dan media sumber belajar mandiri berbasis aplikasi layanan pesan instan WA dapat digunakan untuk meningkatkan motivasi dan hasil belajar peserta didik.
Selain itu, responden juga menyatakan bahwa WA bermanfaat untuk komunikasi, diskusi, dan menanyakan permasalahan kuliah dengan teman sejawat maupun dosen. Penggunaan WA dalam perkuliahan dapat membantu proses komunikasi. Mahasiswa tidak hanya terbatas belajar di kelas dan dalam waktu tertentu. Mahasiswa dapat berkomunikasi lebih mudah dengan dosen untuk bertanya maupun berdiskusi. Selain itu, kesempatan diskusi yang semakin luas dengan optimalisasi penggunaan WA ini dapat meningkatkan semangat belajar mahasiswa. Mahasiswa dapat langsung bertanya jika kurang paham dalam topik tertentu. Seperti yang dinyatakan Usman bahwa cara yang dapat digunakan pendidik untuk memperbaiki keterlibatan peserta didik antara lain dengan meningkatkan persepsi peserta didik secara aktif dalam kegiatan belajar mengajar sehingga mendapatkan respon yang aktif dari peserta didik, melakukan masa transisi antara kegiatan dalam mengajar dengan cepat dan luwes, memberikan materi ajar yang jelas dan tepat sesuai dengan tujuan mengajar yang akan dicapai,mengusahakan agar pengajaran dapat lebih memacu minat peserta didik. Jadi, keaktifan belajar melalui pesan WA salah satu cara yang dapat meningkatkan kemampuan peserta didik secara mandiri dan aktif dalam proses pembelajaran.

\begin{tabular}{|c|c|c|c|c|}
\hline \multirow{2}{*}{ Jumlah Mahasiswa } & \multirow{2}{*}{$\begin{array}{c}\text { Jumlah } \\
\text { Pernyataan }\end{array}$} & \multicolumn{2}{|c|}{ Jawaban Responden } & \multirow{2}{*}{ Jumlah } \\
\cline { 3 - 4 } & Ya & Tidak & \\
\hline 35 & 26 & $94.17 \%$ & $5.83 \%$ & $100 \%$ \\
\hline
\end{tabular}

Tabel 2; Hasil Analisis Data Deskriptif Angket Komentar Responden (Mahasiswa) Terhadap Penggunaan WA Dalam Kegiatan Perkuliahan

Manfaat dari WA ini juga dosen dapat langsung kepada mahasiswa sehingga mereka memberikan pengumuman terbaru melalui WA. dapat langsung mengetahui informasi terbaru Pengumuman ini dapat memberikan notifikasi dalam kegiatan perkuliahan. Penggunaan 
sarana WA untuk memberikan informasi terbaru ini juga mendapat respon yang bagus dari responden karena $94.17 \%$ menghindarkan kesalahpahaman dan memberikan kemudahan dalam mengikuti perkuliahan berikutnya.

Penggunaan WA yang bertujuan untuk berbagi bahan ajar secara daring juga mendapat sambutan yang bagus dari mahasiswa. Hampir semua mahasiswa setuju dengan pengunggahan bahan ajar atau sumber belajar secara daring. Berdasarkan hasil wawancara, responden menyatakan bahwa kemudahan memperoleh bahan ini diharapkan terus berlanjut untuk mempermudah belajar dimanapun dan kapanpun. Penggunaan WA untuk sarana berbagi bahan ajar ini dapat dilakukan melalui laptop maupun smartphone. Tersedianya pilihan untuk berbagi materi perkuliahan ini dapat meningkatkan kesempatan belajar dan berdiskusi bagi mahasiswa tanpa kendala waktu dan tempat.

Penggunaan WA sebagai media pembelajaran pada perkuliahan metodologi penelitian menunjukkan respon positif serta bermanfaat dalam kegiatan pembelajaran. Keefektifan ini disebabkan oleh mudahnya mengakses WA sebagai pesan instan. Penelitian lebih lebih lanjut mengenai penggunaan WA ini sebaiknya dilakukan dengan memfokuskan peranannya dalam meningkatkan prestasi belajar mahasiswa.

\section{KESIMPULAN}

Penelitian mengenai peran penggunaan aplikasi WA sebagai media pembelajaran dalam mata kuliah metodologi penelitian menunjukkan peran positif dalam perkuliahan.
Penggunaan WA dalam perkuliahan dapat membantu mahasiswa berdiskusi langsung dengan sesamanya maupun dengan dosen pengampuh perkuliahan. Kesempatan belajar maupun mengakses materi perkuliahan dapat berjalan lebih efektif dan cepat serta dapat dilakukan kapanpun dan dimanapun.

Penelitian lanjutan sebaiknya dilakukan untuk menyelidiki peranan penggunaan WA untuk meningkatkan prestasi belajar mahasiswa. Peningkatan kualitas jaringan internet sebaiknya dilakukan untuk menjamin semakin optimalnya penggunaan aplikasi IT dalam proses pembelajaran yang lebih menarik dan inovatif.

\section{DAFTAR PUSTAKA}

Ahmadi dan Amri Sofyan. PAIKEM GEMBROT (Pengembangan Pembelajaran Aktif, Inovatif, Kreatif, Efektif, Menyenangkan, Gembira dan Berbobot. Jakarta : PT Prestasi Pustakaraya, 2011.

Aji, Singgih Hutomo. "Pengembangan Aplikasi Layanan Pesan Instan WA Sebagai Sumber Belajar Mandiri Untuk Meningkatkan Motivasi Dan Hasil Belajar Fisika Materi Pokok Efek Rumah Kaca Peserta Didik Kelas XI SMAN 1 Purwokerto." Program Studi Pendidikaan Fisika Fakultas Matematika Dan Ilmu Pengetahuan Alam Universitas Negeri Yogyakarta, (2018): 2, 7, 16, 45 - 46.

Alpiyah, Ulil. "Keaktifan Belajar Siswa

Disekolah Ditinjau Dari Metode Pembelajaran Guru Dan Kelengkapan Fasilitas Sekolah Pada Mata Pelajaran 
Ekonomi Siswa Kelas VII MTS Yasi

Kronggen Tahun Pelajaran 2012/2013.”

FKIP Universitas Muhammadiyah

Surakarta, (2013): 12.

Chiong, Raymond, dkk. "Social Networking,

Teaching, and Learning, Interdiscip." J.

Information, Knowledge, Manag., vol.

7, (2012): 39-43.

Dimyati dan Mudjiono. Belajar dan

Pembelajaran. Jakarta: PT Rineke Cipta, 2006.

Hadi, Baskoro. "Pemanfaatan Aplikasi WA

Pada Pembelajaran Berbasis Blended

Learning di SMKN 1 Sragen." https:// jurnal.fkip.uns.ac.id/index.php/ teknodika/article/view/8276, (2015): 1.

Diakses pada tanggal 10 Februari.

Khairina, Arini Izzati. "Pengembangan Media Sosial WA Sebagai Media Pembelajaran Bahasa Arab di SMP IT Masjid Syuhada Yogyakarta." Program Studi Pendidikan Islam, UIN Sunan Kalijaga, Yogyakarta, (2016): 8.

LCIBS, "The Role of Social Media in Education," London College Of International Business Studies, https:// www.lcibs.co.uk/the-role-of-socialmedia-in-education, 2019. Diakses pada tanggal 12 Februari.

Ma'mun, Ahmad Taufiq. "Efektifitas Pembelajaran Bahasa Arab Melalui Media Sosial WA di Program BISA (Belajar Islam dan Bahasa Arab)." Fakultas Tarbiyah dan Keguruan, UIN Sunan Kalijaga Yogyakarta, (2015): 8.

N, Li, dkk. "Using Social Media for Collaborative Learning in Higher Education: A Case Study Using Social Media for
Collaborative Learning in Higher Education." ACHI (2012): 285-290.

Rina, Dewi. “Akuisisi Facebook Terhadap WA Rampung." http://m.tempo.co/read/ news/2014/10/07/090612453/akuisisi facebook-terhadap-WA-rampung. 2014. Diakses pada tanggal 5 Februari.

Sadiman, Arif S, dkk. Media Pendidikan: Pengertian, Pengembangan, dan Pemanfaatannya. Jakarta: Rajawali Pers. 2010.

Siemens, George. "Connectivism: Learning Theory For The Digital Age." Int. J. Instruc-tional Technol. Distance Learn., (2005): 2-3.

Siregar, Eveline, dkk. Teori Belajar dan

Pembelajaran. Bogor: Ghalia

Indonesia, 2010.

Sudjana, Nana dan Ahmad Rivai. Media Pengajaran. Bandung: Sinar Baru Algensindo, 2013.

Suprihatiningrum, Jamil. Strategi Pembelajaran Teori dan Aplikasi. Yogyakarta: ARRuzz Media, 2013.

Suyudi, Agus dan Khusaini Khusaini. "Optimalisasi Penggunaan WA dalam Perkuliahan Penilaian Pendidikan Fisika," JRKPF UAD, 4. (1), (https://www.researchgate.net/ publication/320221403, 2017): 1-2, 4. Diakses pada tanggal 28 Januari.

Usman, Moh. Uzer. Menjadi Guru Profesional. Bandung: PT Remaja Rosdakarya, 2002. Yamin, Martinis. Kiat Membelajarkan Siswa. Jakarta: Gaung Persada Pres, 2007. 
ISSN: 2085-2541

100 | BIDAYAH: Volume 11, No. 1, Juni 2020 